\title{
Erőmúvek életciklus-elemzése a fajlagos anyagfelhasználás tükrében
}

\author{
Korényi Zoltán \\ Budapesti Műszaki és Gazdaságtudományi Egyetem, Energetikai Gépek és Rendszerek Tanszék, Budapest, Magyarország
}

Beérkezett: 2021. 04. 29.; Elfogadva: 2021. 07. 12.

\begin{abstract}
Összefoglaló
A dolgozat témája a különböző erőmúfajták életciklusra vonatkozó fajlagos anyagigényének a vizsgálata. Az elemzések a nemzetközi szakirodalmi források felhasználásával történtek. Módszere, a bázisadatok elemzése, majd az anyagigényeknek az erőmú beépített teljesítményére és az életciklus alatt megtermelt villamosenergiára vonatkoztatott fajlagos értékek meghatározása. Az eredmények azt mutatják, hogy a nap- és szélerőmúvek elterjedésével a hagyományos erőmúvek által felhasznált fosszilis energiaforrások (pl. a szén) bent maradnak ugyan a földben, de cserébe az új technológia legyártásához a hagyományos anyagokból (beton, acél, alumínium, réz stb.) fajlagosan jóval nagyobb mennyiségekre lesz szükség. Emellett megnő a ritkán előforduló fémek (gallium, indium stb.) felhasználása, ami Európában, a lelőhelyek hiányában, új kockázatokkal jár.
\end{abstract}

Kulcsszavak: erőmú, életciklus-elemzés, anyagigény, anyagellátási kockázat

\author{
Life-cycle analysis of power plants in the light of specific material use \\ Zoltán Korényi \\ Budapest University of Technology and Economics, Department of Energy Engineering, Budapest, Hungary
}

\section{Summary}

The topic of the study is to determine the material use of different power plant types. This is a part of the known life cycle analysis (LCA). The aim of LCA is to determine the impact of human activity on nature. The procedure is described in the standards (ISO 14040/41/42/42). Under environmental impact we mean changes in our natural environment, air, water, soil pollution, noise and impacts on human health. In the LCA, the environmental impact begins with the opening of the mine, continues with the extraction and processing of raw materials, and then with the production of equipment, construction and installation of the power plant. This is followed by the commissioning and then operation of the power plants for 20-60 years, including maintenance. The cycle ends with demolition, which is followed by recycling of materials. The remaining waste is disposed of. This is the complex content of life cycle analysis. Its purpose is to determine the ecological footprint of man.

The method of the present study is to isolate a limited area from the complex LCA process. This means determining the amount of material needed to build different power plants, excluding mining and processing of raw materials. Commercially available basic materials are built into the power plant's components.

The research is based on the literature available in the international area. The author studied these sources, analysed the data, and checked the authenticity. It was not easy because the sources from different times, for different power plants showed a lot of uncertainty. In overcoming the uncertainties, it was a help that the author has decades of experience in the realisation of power plants. It was considered the material consumption related to the installed electricity capacity of the power plant (tons/MW) as basic data.

The author then determined the specific material consumptions, allocated to the electric energy generated during the lifetime, in different power plants.

The calculation is carried out with the help of the usual annual peak load duration hours and the usual lifetime of the power plants.

The results show that with the spread of solar and wind energy, the fossil energy sources previously needed for conventional power plants will remain inside the Earth, but in exchange for the production of new technological equipment from traditional structural materials (concrete, steel, aluminium, copper and plastic), the special need 
multiplies. If we compare the power plants using renewable energy with the electric energy produced during the life cycle of a nuclear power plant, the specific installed material requirement of a river hydropower plant is 37 times, that of an onshore wind farm it is 9.6 times, and that of an outdoor solar power park is 6.6 times higher.

Another important difference is that wind turbines, solar panels and batteries also require rare materials that do not occur in Europe (e.g. gallium, indium, yttrium, neodymium, cobalt, etc.). This can lead to security risks in Europe in the long run.

Keywords: power plant, life-cycle assessment, specific material need, material supply risk

\section{Bevezetés}

Földünk eltartó képessége és az emberiség túlzott természetfogyasztása közötti egyensúly megbomlása, valamint környezetszennyezésünk kritikus helyzete közismert. Amióta a természet élő és élettelen alkotóelemeinek a védelme az emberi figyelem központjába került, a hagyományos erőmúvek, a kibocsátott szennyezőanyagaik miatt, a közbeszédben általában negatív színben jelennek meg. Az óket leváltani szándékozó, megújuló energiát hasznosító erómứvek pedig többnyire szinte csak pozitív jelzőket kapnak. A hagyományos erőmúvek létesítésének erőforrásai a bányászat útján kinyert nyersanyagok (kő, kavics, acél, réz stb.) és a folyamatos üzemeltetéshez szükséges primer energiafajták (szén, földgáz, uránium stb.). A megújuló energiát hasznosító erômứvek esetében a primer energia (a nap és a szél) úgymond „ingyen” jön, ezért csak bányászati erőforrásokra van szükség. A létesítésükhöz szükséges anyagok két csoportra oszthatók: hagyományos anyagokra (beton, acél, réz stb.) és a kevésbé közismert anyagokra (mangán, króm, molibdén, nikkel, szilícium, valamint az ún. ritka földfémek, mint a diszprózium, neodinium, prazeodinium, terbium stb.).

A megújuló energiát hasznosító erőmúvek tehát egyrészt a fosszilis primer energiát bent hagyják a földben, másrészt a hagyományos szerkezeti anyagokon kívül újabb, többnyire drága anyagokat használnak fel.

Jelen tanulmány célja a felhasznált anyagmennyiségek meghatározása, azok fajlagosítása, a különbözó típusú erőmúvek anyagfogyasztásainak az összehasonlítása, és ezekből következtetések levonása. Az időjárásfüggő termelésből származó villamosenergia-felesleg akkumulátoros tárolásának anyagigénye nem tárgya a dolgozatnak.

Civilizációnk létezésének alapfeltétele a villamosenergia-szolgáltatás folyamatossága. Napi életvitelünk villamosenergia nélkül nem lehetséges. A villamosenergia az erőmúvektől kiterjedt vezetékhálózatokon keresztül jut el a fogyasztókig. A hálózatok nagyfeszültségú $(750 \mathrm{kV}$, $400 \mathrm{kV}, 220 \mathrm{kV}, 132 \mathrm{kV})$, középfeszültségú $(35 \mathrm{kV}$, $20 \mathrm{kV}, 10 \mathrm{kV}$ ) és kisfeszültségú vezetékekbő́l állnak, amelyek között transzformátorok biztosítják a feszültségátalakítást. Az erőmúvektől a vezetékhálózaton át a fogyasztói mérőórákig terjedő villamosenergia-ellátó rendszer legfőbb fizikai jellemzője az 50 Hertz frekvencia. Ezt a rendszerirányítónak állandó értéken kell tartania úgy, hogy a folyamatosan változó fogyasztói teljesít- ményekhez minden időpillanatban egyensúlyt biztosító erômüvi betáplálási forrásokat rendel. Ha ez az egyensúly egy elég szúk határon belül nem tartható, akkor a villamosenergia-rendszer összeomlik. Az ilyen, a katasztrófa kategóriájába tartozó események általában ritkán fordulnak elő. (Kaliforniában 2019-ben vihar és erdőtüzek miatt, Texasban, 2021 februárjában regionális „black-out” miatt maradtak milliók áram nélkül. Oka nemcsak a szélsőséges időjárás, hanem leginkább a vezetékhálózatok hiányos múszaki állapota, továbbá a jelentős arányt képviselő időjárásfüggő erómúvek szél- és naphiány miatti állása. Ehhez még egyes hagyományos erőmúvek rendelkezésre állási problémái is hozzájárultak.) A rendszerszintû kockázat folyamatos, ezért annak elkerülése magas színvonalú múszaki rendszert, és múködtetési felkészültséget igényel.

A villamosenergia-rendszerben az erômúvek feladata a primer energia átalakítása villamosenergiává, és annak betáplálása a vezetékes hálózatba. Jelen tanulmány az „egytermékes” erômúvekre fókuszál, amelyek - hőszolgáltatás nélkül - kizárólag villamosenergiát szolgáltatnak. $\mathrm{Az}$ erőmúvek legfontosabb technológiai jellemzője a megbízható ellátásbiztonság.

Magyarország hosszú távú biztonságvédelmi stratégiájában fontos helyen szerepel a villamosenergia-ellátás biztonsága. A primer energiaforrások, a képzett munkatársak, a természeti tényezők, a versenypiaci árak, a pénzügyek stb. kockázatán kívül előtérbe kerültek a nyersanyagok és a kulcsfontosságú múszaki termékek, a pótalkatrészek hozzáférésének geostratégiai kockázatai is. A hagyományos erómúvek alapanyagainak (acél, réz, alumínium, kő, kavics, cement stb.) elérhetősége sok országban biztosított, így ezek esetében a nemzetközi piacon többé-kevésbé kiegyensúlyozott ellátással lehet számolni. Nem ez a helyzet a rohamosan növekvő napés szélerőmúvek területén. A növekvő volumenú napelemek, a szélerőmúvek és az akkumulátorok különleges anyagokat, ritka földfémeket is igényelnek, amelyek közül egyesek előfordulása az egész világon csak néhány országra koncentrálódik.

A különösen kritikus anyagok közé tartoznak a gallium (napelem-vékonyréteg, teljesítményelektronika), a neodym (állandó mágnes, lézer), az indium (napelem vékonyréteg, kijelzők), szkandium (tüzelőanyag-cella, Al-ötvöző), diszprózium (generátor, motorok), a lítium és a kobalt (akkumulátorok). A rézigény is rendkívüli mértékben növekszik. 
Európában eddig az ellátásbiztonság központi témáját a tüzelőanyag-import (főleg a földgáz) jelentette. A jövőben a megújuló energiahasznosítás térhódításával ez kibővül a ritka fémek importjának a kockázatával is. Mivel ezek nyersanyagforrásainak nagy többsége Európán kívül található, felgyorsult e technológiák geostratégiai veszélyeinek a kutatása is.

Az Európai Unióban, de különösen Németországban az „Energiewende” miatt erre különösen nagy súlyt fektetnek.

\section{A vizsgálatok módszertana}

A gyakorlati alkalmazhatóság érdekében elvégzett vizsgálatokhoz értelmezzük először a korlátozott terjedelmú életciklus-elemzést (life-cycle assessment, LCA), az annak alapjául szolgáló szakirodalmat, valamint a fajlagos anyagigények számításának módszerét.

\section{Életciklus-elemzés}

Az ember ökológiai lábnyomának számszerüsítésére a tudomány az életciklus-elemzés módszertanát alkalmazza. Az LCA a termékek, a folyamatok és szolgáltatások teljes életciklusa alatti környezetterhelését vizsgálja. Ez a teljes életút a „bölcsőtől a sírig” tart. Ennek szakaszai: a nyersanyagok kitermelése és feldolgozása, a termékgyártás, a szállítás, az erőmú építési munkálatai és a technológia szerelése, aztán a sokéves üzemeltetési szakasz, végül pedig a lebontás és az újrahasznosítás, illetve a hulladékelhelyezés. Környezetterhelésen a természeti környezetünk megváltoztatását, a levegő, a vizek, a talaj szennyezését, a zajhatást és az emberi egészséget befolyásoló hatásokat értjük. Az életciklus-elemzés eljárásait szabványosították (ISO 14040/41/42/42).

Ez a tanulmány arra vállalkozott, hogy a gyakorlatban legjellemzőbb erőmúveinkre elkészíti a felhasznált anyagok leltárát, majd azt viszonyítja a „hozamhoz”, vagyis a múködési élettartam alatt megtermelt villamosenergia mennyiségéhez. Az anyagok leltárán a beépített szerkezetek és alkatrészek anyagai értendők. A leltárnak nem része a nyersanyag-kitermelés és -feldolgozás anyagmérlege, valamint a múködési élettartam alatt beépített cserealkatrészek. Az LCA ezen szúkített terében kapott fajlagos anyagfelhasználási mutatók alkalmasak arra, hogy a különböző erőmúveket mint „anyagfogyasztókat", a környezeti beavatkozás szempontjából is összehasonlítsuk. Alkalmas továbbá arra is, hogy az erômúvi stratégiák készítésekor a beszerzési, a szállítási, a raktározási és az építési volumeneket megbecsüljük.

\section{Szakirodalmi visszatekintés}

A környezetvédelem erőteljes előtérbe kerülésével, a megújuló energiahasznosítás felgyorsulásával, Németországban az „Energiewende” bevezetésével, az életciklus- elemzés szabványosított (ISO 14040) módszertanát felhasználva, az 1990-es évek második felében felgyorsultak azok a kutatások, amelyek az ökológiai lábnyomok számszerü vizsgálatát tűzték ki célul. Ennek élenjáró szellemi múhelyei lettek a svájci ETH Zürich, az USA-beli National Renewable Energy Laboratory (NREL), a Stuttgarti Egyetemen az Institut für Energiewirtschaft und Rationelle Energieanwendung (IER), Münchenben a Forschungsstelle für Energiewirtschaft (FfE), Norvégiában a Trondheimi Egyetem, a Norwegian University of Science and Technology (NTNU) és még sokan mások. Ezeknek a kutatásoknak fontos célja volt az is, hogy elemezzék az ellátásbiztonság szempontjából kritikus anyagokat, azok földrajzi előfordulását, a jövőbeli elérhetőségét, a geopolitikai, a helyi társadalmi és politikai kockázatokat. Az EU-ban ezt szolgálja az Európai Bizottság Joint Research Centre (JRC) tudományos szervezete is.

Az áttanulmányozott irodalmi forrásokból kiderül, hogy az erőmúvek anyagmérlegének precíz, általánosítható, tudományos pontosságú meghatározása a jelenlegi adatbázisok szintjén aligha lehetséges. Ennek számos oka van. A legjellemzőbb, hogy mivel a megépített erőmúvek kapacitása és technológiája a hely szerint (folyóvíz, talajmechanikai adottságok, klimatikus viszonyok, magasságszintek, helyi elő́rások stb.), időben is, a megrendelő szándéka és a komponensek gyártói konstrukciója szerint változik. Vagyis az erőmű nem szériatermék. Az erőmúépítés jellemzően több évig tartó folyamata, a közben fejlődő technológiák, az új anyagfajták, anyagminőségek is hozzájárulnak a változékonysághoz.

Ezen bizonytalanságokon túl nehézséget jelent az adatok hozzáférése, azok begyưjtése, későbbi validálhatósága, a sokféleség miatti rendszerbe szedése. Ilyen nemzetközi adatgyújtési elő́rások sem léteznek. A szerző által áttanulmányozott források is visszatükrözik ezeket a nehézségeket. Az ellenmondásos adatoknál, a kiválasztás egyes eseteinél segített a szerző évtizedes erőmúl-létesítési tapasztalata is.

A felhasznált források közül az egyik legrégebbi, legrészletesebb tanulmány (Briem et al. 2005) a német Gazdasági Minisztérium megbízásából készült. Célja az volt, hogy a kiválasztott technológiákra (tüzelőanyag-cella, szélerőmúvek, biomassza és fosszilis erőmúvek) a 2010. esztendőig előrevetítve végezzen életciklus-vizsgálatot. A Stuttgarti Egyetem energetikai intézetének (IER) szellemi múhelyében készült elemzések közül (Marheineke 2002) a teljes életciklusukra vonatkozó környezetterhelésekre koncentrál, az anyagfelhasználásokat a bánya szintjén értelmezi (bauxit, vas, réz és mészkő). Erre is építve készült (Mayer-Spohn et al. 2007) jelentése, amely a modellszámításaik eredményeit a teljes életciklus alatti kummulált anyag, energia és kibocsátási mérlegre vonatkoztatja, kiegészítve a károsanyag-kibocsátások emberi egészségre gyakorolt kockázatával, amelyet az „elvesztett emberi életévek" (Years of Life Lost, YOLL) indikátorral számszerüsít. A stuttgarti iskola”, társintézmé- 
nyeket is bevonva, az „Energiewende” hatásaira és kihívásaira keresi a választ. A nap- és szélerômúvek nagymértékú kapacitásbővítésének két komoly hatása van. Egyrészt a nap- és szélenergia kicsi energiasúrúsége $\left(\mathrm{W} / \mathrm{m}^{2}\right)$ miatti nagy fajlagos anyagfelhasználás nagymértékben megnöveli a hagyományos anyagok (beton, acél, aluminium, réz, üveg és műanyag) fajlagos mennyiségi igényét. Másrészt új, speciális anyagokra van szükség. A szélerőmúvek generátoraihoz neodym és diszprózium, a napelemekhez pedig - típusaik szerint - szilícium, kadmium, indium, gallium, diselenit stb. szükséges. Ez a folyamat a nyersanyagok szúkössége és Európa számára hátrányos földrajzi lelőhelyei miatt a jövőben nagy kockázatokat jelenthet. Erre több tanulmány keresi a választ (Blengini et al. 2020; Carrara et al. 2020; Wetzel 2015; 2016).

A felhasznált tanulmányokból megállapítható, hogy az adatgyüjtés fent vázolt nehézségei miatt az erőmúvek tonnában vagy t/MW értékkel megadott anyagfelhasználási értékei nagy szórásokat mutatnak. Az alapul vett adatbázis mintegy 130 értéket tartalmaz. Ebben a szórások, a szén- és földgáztüzelésû erőmúveknél a betonigény esetében $\pm 50 \%$-on belüli, az acéligénynél \pm 30 - $40 \%$ nyi, rézigénynél 30-70\% tartományban voltak megállapíthatók. A nap- és szélerőmúveknél az acéligény szórása 20\%-nyi, a rézigény 30-70\%-os tartományban mozgott. A nemzetközi irodalomban általában az erőmúvekre elvégzett LCA elemzések többsége fóleg a $\mathrm{CO}_{2}$-kibocsátásokra, az energiahozamokra, az ökológiai és humán hatásokra koncentrál. A felhasznált anyagmennyiségek elemzése fóleg a napelemek és az akkumulátorok kapcsán, csak az utóbbi időben kapott nagyobb lendületet. A fent leírtak miatt ezért célszerű már a bázisadatokat is kellő óvatossággal kezelni. Az életciklus alatt megtermelt villamosenergiára vonatkoztatott fajlagos anyagmennyiségek is eltérőek lehetnek aszerint, hogy az esztendő 8760 naptári órájához képest mekkorára veszszük fel az éves csúcskihasználási óraszámokat, továbbá hány évre adjuk meg a múködési élettartamot.

\section{Az erömüvekbe beépitett anyagok fajlagos tömegének meghatározása}

A fajlagos anyagfelhasználást a következő két egyenlettel értelmezhetjük:

- a beépített anyagok tömegét, a beépitett villamos teljesitményre vonatkoztatva:

$$
\mathrm{M}=\mathrm{m}_{\mathrm{P}} \cdot \mathrm{P}[\text { tonna }]
$$

ahol:

$\mathrm{M}[\mathrm{t}] \mathrm{S} \quad$ a beépített anyagok tömege;

$\mathrm{m}_{\mathrm{P}}[\mathrm{t} / \mathrm{MW}]$ : fajlagos anyagmennyiség a beépített vil-

lamos teljesítményre vonatkoztatva;

P [MW]: beépített villamos teljesítmény.
- a beépített anyagok tömegét a múködési élettartam alatt megtermelt villamos energia mennyiségére vonatkoztatva:

$$
\mathrm{M}=\mathrm{m}_{\mathrm{E}} \cdot \mathrm{P} \cdot \tau_{\mathrm{cs}} \cdot \mathrm{i} \cdot 10^{-3}[\text { tonna }]
$$

ahol:

$\mathrm{M}[\mathrm{t}]:$ a beépített anyagok tömege;

$\mathrm{m}_{\mathrm{E}}[\mathrm{kg} / \mathrm{MWh}]$ : fajlagos anyagmennyiség az életciklus alatt megtermelt villamos energiára; $\mathrm{E}=\mathrm{P} \cdot \tau_{\mathrm{cs}} \cdot \mathrm{i}$

$\mathrm{P}[\mathrm{MW}]$ beépített villamos teljesítmény;

$\tau_{\mathrm{cs}}[\mathrm{h} / \mathrm{év}]: \quad$ csúcskihasználási óraszám (a 8760 órá-

i [év]: $\quad$ hoz képest);

\section{A vizsgált erőmúvek és alapadataik}

Vizsgálataink szempontjából a villamosenergiát termelő erőmúveket két csoportra osztjuk:

- hagyományos erômüpek: kőszén- és barnaszén-tüzelésû, földgáztüzelésű (nyitott gázturbina ciklusú és kombinált gôz-/gázturbina ciklusú), valamint atomerőmúvek;

- megújuló energiát hasznositó erőmüvek: időjárásfüggő, változékony teljesítményű, nap- és szélerőművek, a folyami vízerőmúvek és a szabályozható biomasszatüzelésû erőmúvek.

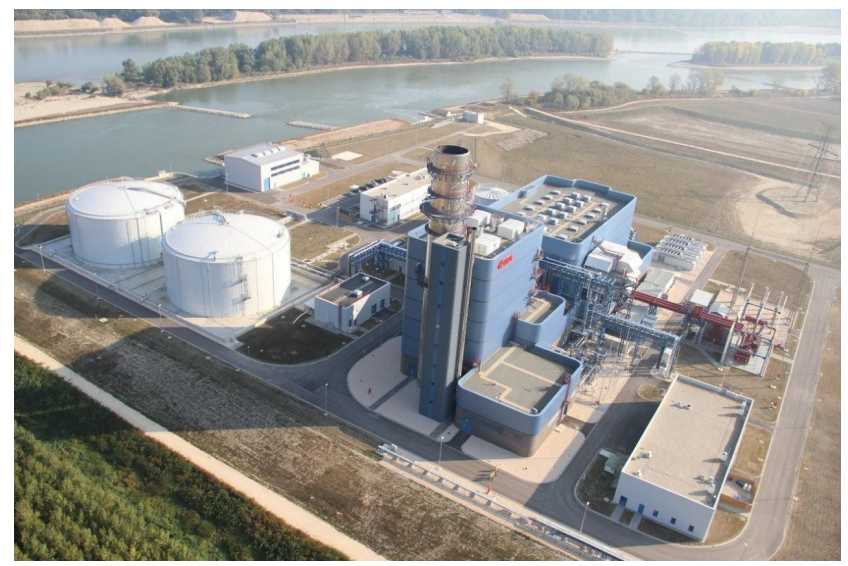

1. ábra $\quad$ A Gönyúi Erőmű (saját forrás)

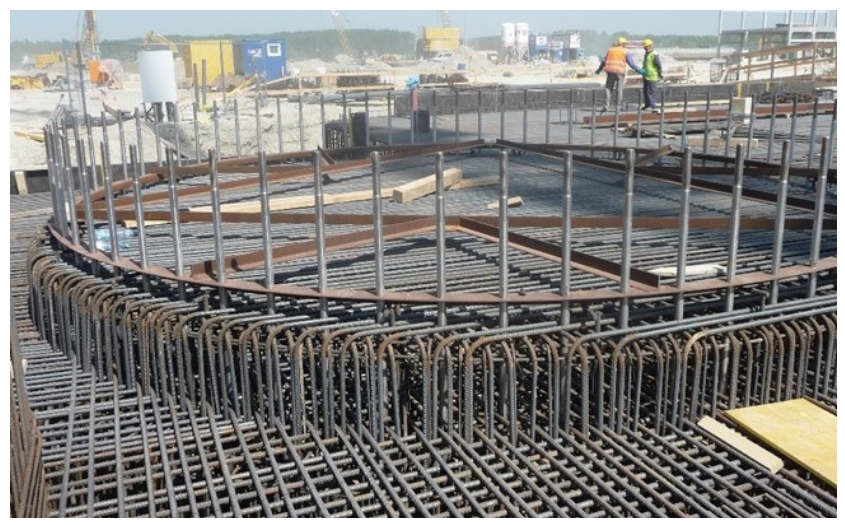

2. ábra $\mid$ Kémény- és kazánalapozás (saját forrás) 
Annak érdekében, hogy az energetikában nem járatos olvasónak is legyen elképzelése a valóságos erőmúvekról, közzéteszünk néhány fényképet a szerző saját tapasztalati múltjából. Az 1. ábra a Győr közelében, a Duna partján megépített, folyóvízhűtésû kombinált ciklusú (gázés gőzturbinás) Gönyúi Erőmúvet mutatja. Beépített villamos teljesítménye $433 \mathrm{MW}$, a beépített gázturbina tömege 200 t, a gőzturbináé 200 t, a főtranszformátoré 400 t. A 2. ábra a $60 \mathrm{~m}$ magas kémény és a $25 \mathrm{~m}$ magas hőhasznosító-kazán alapozását mutatja.

A 3. ábra Magyarország első közcélú, 2001-ben üzembe helyezett, $20 \mathrm{kV}$-os hálózathoz csatlakozó széltornyát, a Kulcsi Szélerőmúvet mutatja. A torony $65 \mathrm{~m}$ magas, a rotor átmérője $44 \mathrm{~m}$, teljesítménye $600 \mathrm{~kW}$. A torony tömege 90 t. A 14 m átmérőjű vasbeton alapja gombafej alakú, amelybe $120 \mathrm{~m}^{3}$ betont építettek be. Európában, szárazföldi (on-shore) kivitelben általában a 2-3 MW körüli széltornyok terjedtek el.

A 4. ábra egy széles körben elterjedt, tipikus szabadtéri, horganyzott acéllábakon álló napelem park paneljeit mutatja. Területigényüket tájékoztató jelleggel, 1 ha/MW körüli értékkel lehet becsülni. A piacon elterjedt napelem modulok többségükben szilícium alapanyagú monokristályos és polikristályos technológiával készülnek.

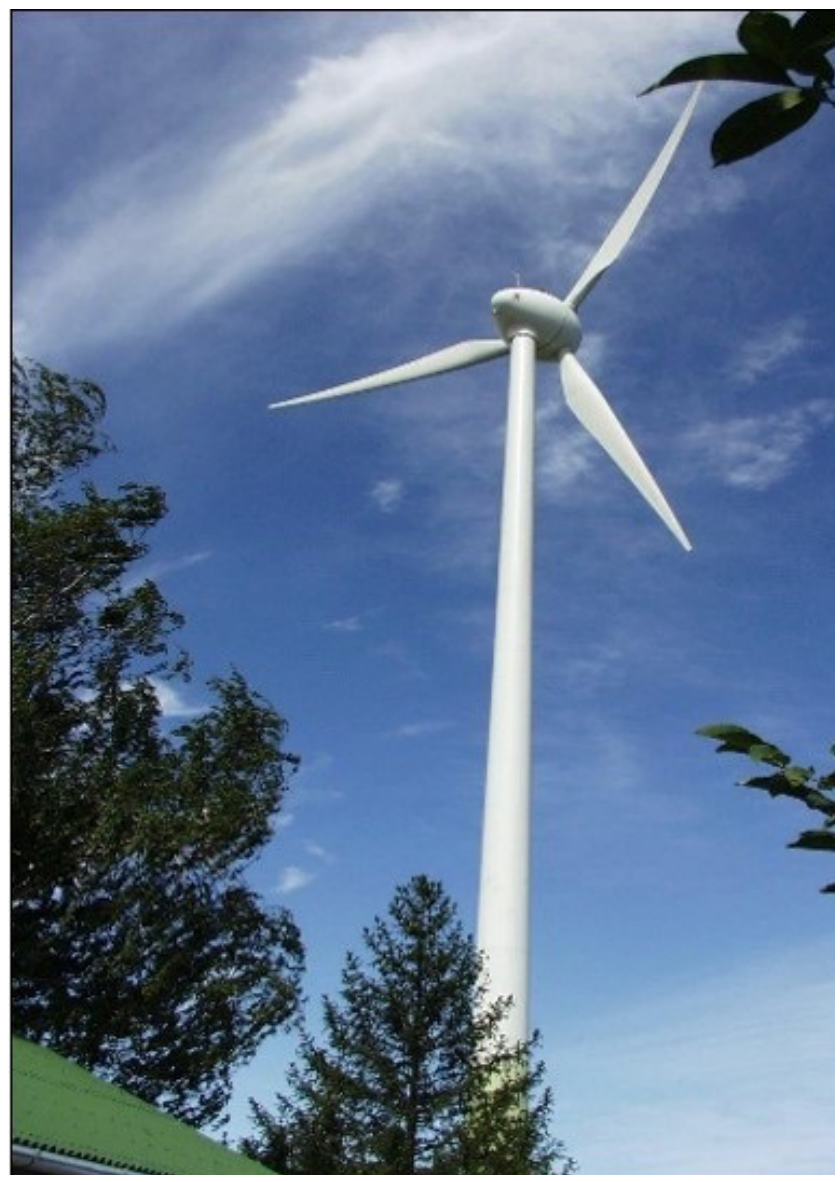

3. ábra

| Kulcsi Szélerőmű (saját forrás)

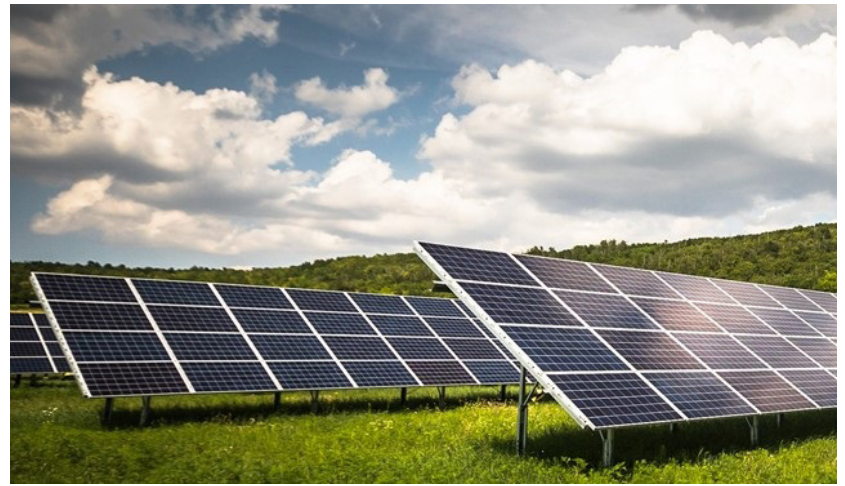

4. ábra $\quad$ Napelem park (Fotó: Bóka Zsuzsa)

\section{Az erômüvek anyagfelhasználási bázisadatai}

Az irodalmi adatok feldolgozását követően az erőmúvek fajlagos anyagigényeit, az $\mathrm{m}_{\mathrm{P}}$ [tonna/MW] jellemzővel, a szerző az 1. táblázatban foglalta össze. (A táblázat számai a következő forrásokra támaszkodnak: Briem et al. 2005; Wetzel 2015; 2016; Carrara et al. 2020; Marbeineke, 2002; Mayer-Spobn et al. 2007.) A szélerőmüvek esetén a táblázatban a nem hagyományos anyagok (összesen 1,8 t/MW) nincsenek külön kimutatva, de az „Összes” oszlop száma tartalmazza ezeket. Ezen, nem hagyományos anyagok közé tartoznak a generátor állandó mágneséhez szükséges neodym és diszprózium, továbbá króm, mangán, molibdén, nikkel, praseodymium és terbium.

Hasonlóan a naperőmúvek 2. és 3. tételénél is az „Összes” oszlop tartalmazza a táblázatban nem feltüntetett szilíciumot $(4 \mathrm{t} / \mathrm{MW})$ és ezüstöt $(0,02 \mathrm{t} / \mathrm{MW})$ is.

A hagyományos erőmúvek esetében a táblázat „Öszszes" tételén felül, az „egyéb anyagok” mennyisége többletként 0,5-1,5\%-ra tehető.

A különböző erőművek életciklus alatt megtermelt villamosenergia-mennyiségeinek kiszámításához szükség van az éves csúcskihasználási óraszámokra és az üzemeltetés éveinek a számára. Ezeket a gyakorlatban használatos adatokat a 2. táblázat tartalmazza. A szél- és naperőmúvek csúcskihasználási óraszámai a hazai meteorológiai körülményeket veszik figyelembe.

\section{A vizsgálatok eredményei}

Az 1. és 2. táblázatban szereplő adatok felhasználásával, a fenti egyenletek alapján elvégzett, életciklus alatt termelt villamos energiára vonatkoztatott fajlagos anyagmennyiségek $\left(\mathrm{m}_{\mathrm{E}}\right)$ értékeit a 3. táblázat tartalmazza. A táblázat számai azt mutatják meg, hogy egy adott erómú teljes múködési életciklusában megtermelt villamosenergia egy kilowattórájára hány kilogramm beépített anyag jut.

A 3. táblázat számait megvizsgálva láthatjuk, hogy a megújuló energiát hasznosító víz-, szél- és naperőmưvek fajlagos anyagfelhasználása többszöröse a hagyományos 
1. táblázat | Hagyományos anyagok teljesítményre vonatkoztatott fajlagos mennyiségei $\left(\mathrm{m}_{\mathrm{P}}\right)$

\begin{tabular}{|c|c|c|c|c|c|c|c|c|}
\hline \multirow{2}{*}{$\begin{array}{l}\text { S. } \\
\text { sz. }\end{array}$} & \multirow{2}{*}{$\begin{array}{l}\text { Erómúvek } \\
\text { fajtái }\end{array}$} & Beton & Acél & Alumínium & Üveg & Réz & Múanyag & Összes \\
\hline & & $\mathrm{t} / \mathrm{MW}$ & $\mathrm{t} / \mathrm{MW}$ & $\mathrm{t} / \mathrm{MW}$ & $\mathrm{t} / \mathrm{MW}$ & $\mathrm{t} / \mathrm{MW}$ & $\mathrm{t} / \mathrm{MW}$ & $\mathrm{t} / \mathrm{MW}$ \\
\hline 1. & Szélpark - szárazföld & 369 & 152,1 & 0,7 & 8,0 & 2,1 & 4,60 & 538 \\
\hline 2. & Naperömü - tetőn & 0 & 16,2 & 44,7 & 80,49 & 10,7 & 6,57 & 129 \\
\hline 3. & Naperőmú - szabadtéren & 61 & 67,9 & 7,5 & 80,49 & 26,6 & 8,6 & 222 \\
\hline 4. & Biomassza & 159 & 51,0 & 1,3 & 0,003 & 0,6 & 0,1 & 212 \\
\hline 5. & Vízerőmú - folyami duzzasztással & 11026 & 203,9 & 0,1 & 0,001 & 3,12 & 0,1 & 11234 \\
\hline 6. & Barnaszénerőmü & 250 & 100,0 & 0,6 & 0,0208 & 1,3 & 1,0 & 353 \\
\hline 7. & Feketeszén-erőmú & 250 & 80,0 & 0,6 & 0,0217 & 1,3 & 1,0 & 333 \\
\hline 8. & Kombinált ciklusú erőmú & 98 & 31,0 & 0,2 & 0,12 & 0,62 & 0,47 & 130 \\
\hline 9. & Atomerômü & 424 & 63,1 & 0,21 & 0,01 & 1,52 & 0,1 & 489 \\
\hline
\end{tabular}

(Saját szerkesztés)

2. táblázat |Az erômúvek múködési életciklusának adatai

\begin{tabular}{|c|c|c|c|c|}
\hline \multirow{2}{*}{$\begin{array}{l}\text { S. } \\
\text { sz. }\end{array}$} & \multirow[t]{2}{*}{ Erőmúvek fajtái } & Fajlagos beépített össztömeg & Csúcskihasználási óraszám $\left(\tau_{\mathrm{cs}}\right)$ & Élettartam \\
\hline & & $\mathrm{t} / \mathrm{MW}$ & h/év & év \\
\hline 1. & Szélpark - szárazföldön & 538 & 2200 & 25 \\
\hline 2. & Naperőmü - tetőn & 129 & 1000 & 30 \\
\hline 3. & Naperőmü - szabadtéren & 222 & 1100 & 30 \\
\hline 4. & Biomassza tüzelésü (faapríték) & 212 & 7000 & 30 \\
\hline 5. & Vízerómú - folyami duzzasztással & 11234 & 5000 & 60 \\
\hline 6. & Barnaszénerómú & 353 & 7000 & 35 \\
\hline 7. & Feketeszén-erômü & 333 & 7000 & 35 \\
\hline 8. & Kombinált ciklusú erômü & 130 & 7500 & 30 \\
\hline 9, & Atomerómú & 489 & 8000 & 60 \\
\hline
\end{tabular}

(Saját forrás)

3. táblázat | Hagyományos anyagok életciklus alatt megtermelt villamos energiára vonatkoztatott fajlagos mennyiségei $\left(\mathrm{m}_{\mathrm{E}}\right)$

\begin{tabular}{|c|c|c|c|c|c|c|c|}
\hline \multirow{2}{*}{$\begin{array}{l}\text { S. } \\
\text { sz. }\end{array}$} & \multirow[t]{2}{*}{ Erômúvek fajtái } & Beton & Acél & Alumínium & Üveg & Réz & Múanyag \\
\hline & & $\mathrm{kg} / \mathrm{MWh}$ & $\mathrm{kg} / \mathrm{MWh}$ & $\mathrm{kg} / \mathrm{MWh}$ & $\mathrm{kg} / \mathrm{MWh}$ & $\mathrm{kg} / \mathrm{MWh}$ & $\mathrm{kg} / \mathrm{MWh}$ \\
\hline 1. & Szélpark - szárazföldön & 6,709 & 2,765 & 0,0127 & 0,145 & 0,0382 & 0,08364 \\
\hline 2. & Naperőmü - tetőn & 0,000 & 0,541 & 1,4890 & 2,683 & 0,3567 & 0,21900 \\
\hline 3. & Naperőmú - szabadtéren & 1,839 & 2,058 & 0,2273 & 2,439 & 0,8061 & 0,26061 \\
\hline 4. & Biomassza-erómú & 0,757 & 0,243 & 0,0062 & 0,0000 & 0,0029 & 0,00048 \\
\hline 5. & Vízerômú - folyami duzzasztással & 36,754 & 0,680 & 0,0003 & 0,0000 & 0,0104 & 0,00033 \\
\hline 6. & Barnaszénerômü & 1,020 & 0,408 & 0,0024 & 0,0001 & 0,0053 & 0,00408 \\
\hline 7. & Feketeszén-erőmú & 1,020 & 0,327 & 0,0024 & 0,0001 & 0,0053 & 0,00408 \\
\hline 8. & Kombinált ciklusú erőmú & 0,435 & 0,138 & 0,0009 & 0,0005 & 0,0028 & 0,00207 \\
\hline 9. & Atomerőmú & 0,884 & 0,131 & 0,0004 & 0,00002 & 0,0032 & 0,00021 \\
\hline
\end{tabular}

(Saját számitások)

erőmúvek fajlagos anyagigényeinek, ahol a vízerőmúvek tömege nagyobbrészt beton. A sok szám közötti tájékozódás megkönnyítésére vezessük be a relatív anyagfelhasználási mutatót. Mivel az atomerömüvekhez közismerten nagy mennyiségú beton és acél szükséges, válasszuk azt összehasonlítási alapul. Legyen az atom- erômű életciklusa alatt megtermelt villamosenergiára vonatkoztatott anyagigénye $\left(m_{\mathrm{E}}\right)$ egységnyi, $A=1$. A többi erőmű́nél azt vizsgáljuk, hogy az ő esetükben az atomerőmúhöz képest hányszoros (n) anyagmennyiséget kell beépíteni $(\mathrm{n} \times \mathrm{A})$. Ezeket a relatív anyagfelhasználási értékeket mutatja a 4. táblázat. 
4. táblázat | Erőmúvek életciklus alatti villamosenergiára vonatkoztatott relatív anyagfelhasználása. Referencia: atomerőmú, $\mathrm{A}=1$ egységnyi

\begin{tabular}{|c|c|c|c|c|c|c|c|}
\hline \multirow{2}{*}{$\begin{array}{l}\text { S. } \\
\text { sz. }\end{array}$} & \multirow{2}{*}{$\begin{array}{l}\text { Erómúvek } \\
\text { fajtái }\end{array}$} & Beton & Acél & Alumínium & Üveg & Réz & Múanyag \\
\hline & & $\mathbf{n} \times \mathbf{A}$ & $\mathbf{n} \times \mathbf{A}$ & $\mathbf{n} \times \mathbf{A}$ & $\mathbf{n} \times \mathbf{A}$ & $\mathrm{n} \times \mathrm{A}$ & $\mathbf{n} \times \mathbf{A}$ \\
\hline 1. & Szélpark - szárazföldön & 7,6 & 21 & 29 & 6982 & 12 & 401 \\
\hline 2. & Naperômú - tetôn & 0,0 & 4,1 & 3403 & 128784 & 113 & 1051 \\
\hline 3. & Naperőmü - szabadtéren & 2,1 & 16 & 519 & 117076 & 255 & 1251 \\
\hline 4. & Biomassza-erômú & 0,9 & 1,8 & 14 & 0,7 & 0,9 & 2,3 \\
\hline 5. & Vízerőmú - folyami duzzasztással & 42 & 5,2 & 0,8 & 0,2 & 3,3 & 1,6 \\
\hline 6. & Barnaszénerőmü & 1,2 & 3,1 & 5,6 & 4,1 & 1,7 & 20 \\
\hline 7. & Feketeszénerômü & 1,2 & 2,5 & 5,6 & 4,3 & 1,7 & 20 \\
\hline 8. & Kombinált ciklusú erőmű & 0,5 & 1,0 & 2,0 & 26 & 0,9 & 10 \\
\hline 9. & Atomerómú. $\mathrm{A}=$ & 1 & 1 & 1 & 1 & 1 & 1 \\
\hline
\end{tabular}

(Saját forrás)

A 4. táblázat számai alapján megállapítható, hogy amikor a megújuló energiát hasznosító erőmúvek fosszilis energiaforrásokat váltanak ki, akkor cserébe, a szerkezeti elemek gyártásához, Földünk hegyeiből és a földfelszín alól sokszoros mennyiségú más anyagot kell kitermelni.

Az össztömegen belül betonból a folyami duzzasztott vizerömü 42-szer, a szélpark 7,6-szer, a szabadtéri naperómü park (a lábazat alapjaihoz) 2,1-szer annyi betonmenynyiséget igényel, mint egy atomerőmú. Acélból a folyami vizerömünek 5,2-szer, a szabadtéri naperömü parknak 16 szor, a szélparknak 21-szer nagyobb a relatív acéligénye. Aluminiumból a naperómüpek 500-szoros, illetve több ezerszeres fajlagos alumíniummennyiséget igényelnek. A napelemek óriási üvegigénye mindenki számára nyilvánvaló. A naperömüvek rézigénye 100-200-szoros, a müanyag-felhasználásuk pedig nagyságrendileg 1000-szeres.

A naperómúvek esetén megjegyezzük, hogy a fenti vizsgálatok a jelenlegi piac 95\%-át kitevő mono- és polikristályos szilícium alapanyagú modulokat veszik figye- lembe. Nem foglalkoznak a piac 4-5\%-át jelentő vékonyfilmes napelem technológiákkal (CdTe, CIGS és a-Si). Ezek a szilíciumon és ezüstön kívül fóleg az Európában nem előforduló anyagokat (kadmium, tellúr, indium, gallium, szelénium, germánium) használják.

Természetesen a táblázatok számai - az irodalmi áttekintésnél leírtak miatt - a változatos, nem mindig beazonosítható körülmények okán, meglehetôsen nagy bizonytalanságot mutatnak. Az arányok és a tendenciák viszont olyan súlyúak, hogy azokat az egyes technológiák komplex értékelésénél, az életciklus-elemzésekben, az ökológiai lábnyom vizsgálatánál nem lehet figyelmen kívül hagyni.

A végeredményt vizuálisan is alátámasztva, az egyes erőmúvi technológiák életciklusra vonatkoztatott acéligény szerinti sorrendjét az 5. ábrán mutatjuk be. A rézigények szerinti sorrend a 6 . ábrán látható.

Belátható, hogy a fentiekben bemutatott fajlagos anyagjellemzők egyrészt árnyalják a „megújuló” energiahasznosítás ökológiailag csak előnyösnek hirdetett meg-

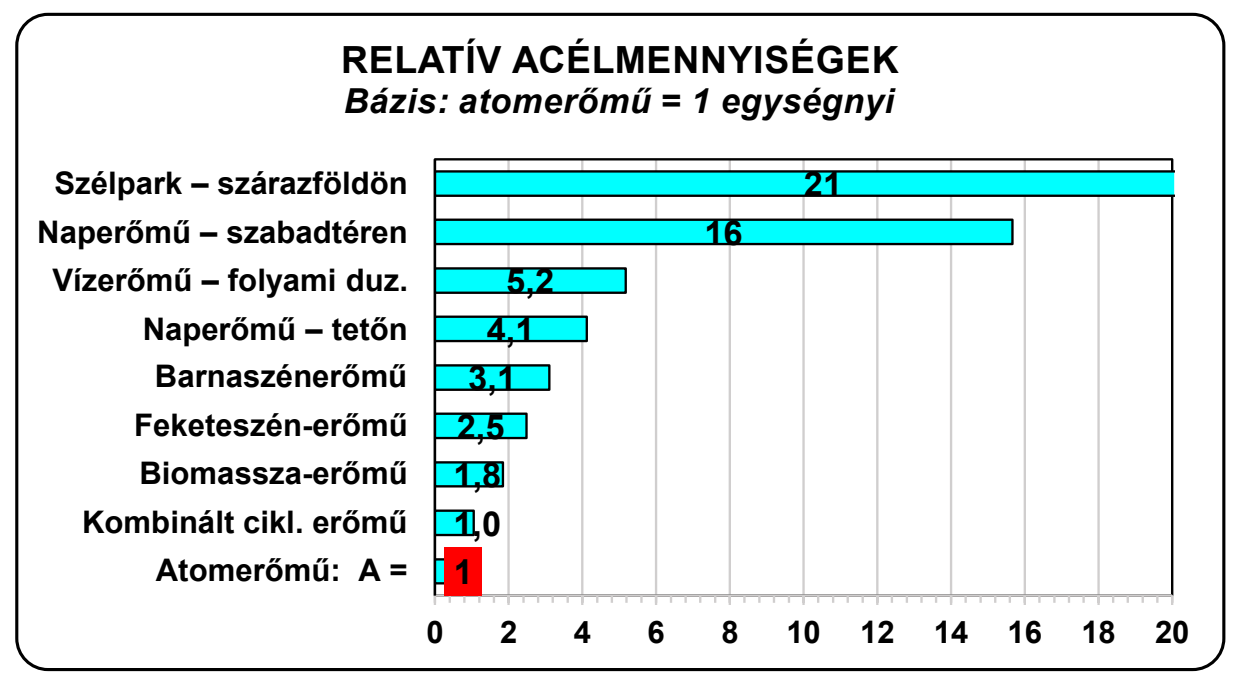

5. ábra

| Életciklusra vonatkoztatott acélfelhasználások relatív sorrendje (Saját forrás) 


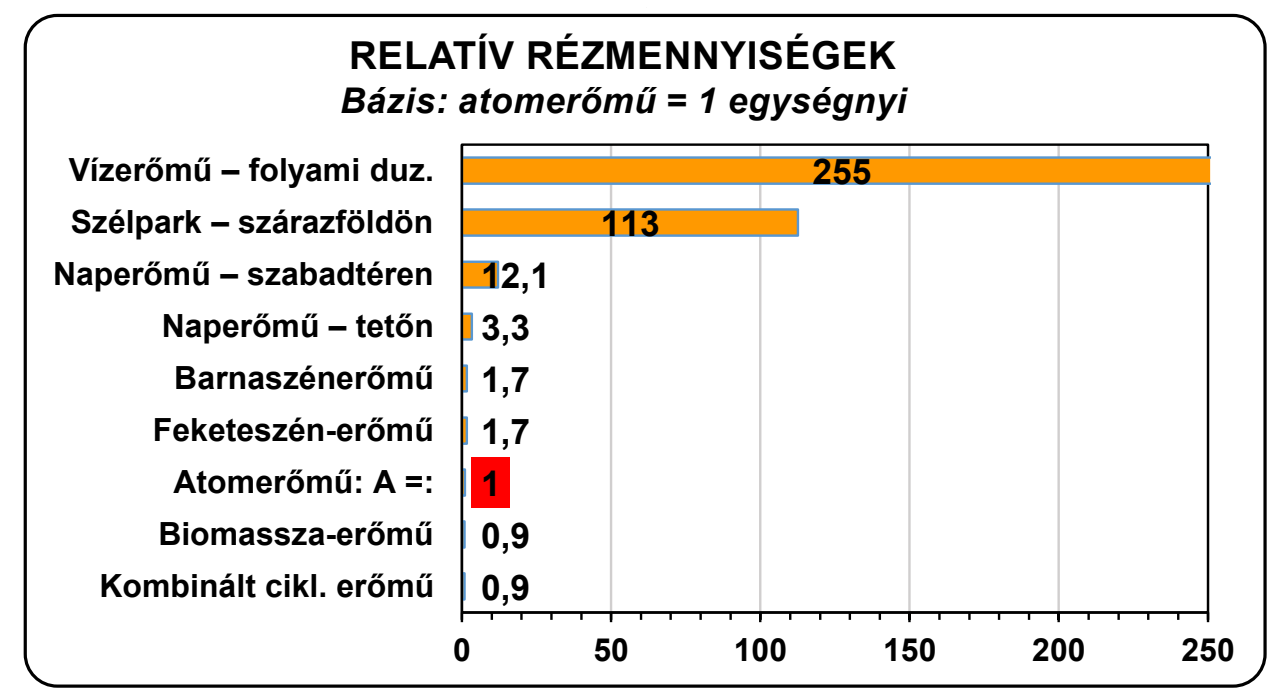

6. ábra

| Életciklusra vonatkoztatott rézfelhasználások relatív sorrendje (Saját forrás)

oldásait, másrészt a nemzetgazdaság számára is fontos szempontok további vizsgálatára sarkallhatják az illetékeseket.

\section{Összefoglalás}

A környezetvédelem, az energetikai ellátásbiztonság és bizonyos nemzetbiztonsági szempontok is indokolttá teszik, hogy a hazai erőmúvi portfólió tervezésénél a beépítésre kerülő technológiák anyagfajtáit, a szükséges anyagmennyiségeket, azok földrajzi előfordulásait is a nemzetgazdasági tervezés fókuszába helyezzük. Az Európai Unióban külön szervezet (JRC) felelős ezért.

Jelen tanulmány azt a célt tûzte ki, hogy a rendelkezésre álló szakirodalmi források alapján értékelje az erőmúvek fajlagos anyagfelhasználásának a helyzetét. A fenti elemzésekből kiderül, hogy nem állnak rendelkezésre olyan, statisztikailag nagyszámú elemet tartalmazó adatbázisok, amelyekből a különféle erőmútípusokra megbízható, valós anyag-felhasználási értékek nyerhetők. Ez jelenleg az erőmüvi technológiák sokszínúsége miatt nem is várható el.

A kapott eredmények - e vázolt körülmények figyelembevételével - alkalmasak a természetfogyasztásunk megítélésére, a stratégiai irányaink továbbgondolására és a tendenciák további elemzéseire.

A vizsgálatokból levonható elsö üzenet gyakorlati jellegü: a fajlagos anyagigények ismerete segítséget jelenthet a nemzetgazdasági tervezés (beszerzési és szállítási volumenek, raktározás, a körkörös gazdaság tervezése, a komplex folyamatok költségelemzése stb.) számára.

A második üzenete az, hogy az emberiség ökológiai lábnyomait a megújuló energia hasznosításának mértéken felüli elterjesztése nem fogja eltüntetni, mert az anyagfelhasználása sokszorosára nó. Ennek oka, hogy az új technológiák kétségkívül visszafogják a fosszilis energiaforrások kitermelését, de cserébe a Föld más földrajzi helyein felgyorsítják az egyes nyersanyagok kitermelését. Megtöbbszöröződik a hagyományos anyagok (kő, kavics, acél, réz), a nemesfémek és különleges anyagok (szilícium, ezüst, króm, mangán, molibdén, nikkel, kobalt, lítium stb.) kibányászása. Soha nem látott mértékben lesz szükség a földfémekre és a ritka földfémekre (alumínium, gallium, indium, ittrium, neodímium, terbium, szamárium stb.), vagyis a fosszilis energiaforrások kitermelését más nyersanyagok kibányászása váltja fel.

A harmadik üzenete, hogy a természetfogyasztásunk és ezzel a hulladéktermelésünk mértékét nem az új technológiákkal, hanem alapvetően fogyasztásunk csökkentésével lehet csak megoldani. Mivel a nagymértékú fogyasztáscsökkenés jelenleg irreálisnak tűnik, ezért már most fel kell készülni arra, hogy a nap- és szélerőmúvek 25-30 év múködés után lebontásra kerülnek. Kiemelt fontosságú feladattá válik, hogy a megnövekedett menynyiségű bontási anyagokat hogyan tudjuk újrahasznosítani, hogyan tudjuk beilleszteni a körkörös gazdaság folyamataiba.

A negyedik üzenete, hogy Európa számára megjelenik egy új geostratégiai biztonsági kockázat, mivel az új, különleges anyagok itt nem találhatók meg. Egy esetleges krízishelyzetben az alkatrészek pótlásának ellehetetlenülése drasztikus árnövekedést okozhat és blokkolhatja az energiaszolgáltatást. Adott, nem várt esetben, nemzetbiztonsági kérdéssé is válhat.

Az ötödik üzenet kapcsolódik a 2020-ban kiadott Nemzeti Energiastratégia 2030 dokumentumhoz (NES2). Eszerint 2021-2030 között meg fog épülni a Paks 2 Atomerőmü (2200 MW). További naperőmúvek (+4650 MW) létesülnek (a fele háztetőn, fele szabadtéren). Három kombinált ciklusú erőmú (1800 MW) és biomassza erőmúvek (400 MW) fognak megépülni.

Ezeknek az erőmúveknek a fenti módszer szerint becsült anyagmennyiség-igénye: kb. 2,2 millió tonna tömegû. Tételezzük fel, hogy ezt az anyagmennyiséget 20 
tonnás teherautókkal szállítjuk az erőmúvi telephelyekre. A Paks 2 atomerómú anyagaihoz 54 ezer, a naperómúvek anyagaihoz 41 ezer, a kombinált ciklusú erőmúvek anyagaihoz 12 ezer és a biomassza erőmúvek anyagaihoz kb. 5 ezer fuvarra lesz szükség. Ez 2030-ig összesen 112 ezer teherfuvar lebonyolítását jelenti. Ezen becsült adatok alkalmasak lehetnek további költség- és környezetterhelési számítások elvégzésére is.

Zárásként tehát kijelenthető, hogy a fajlagos anyagigények fent meghatározott eljárása az ökológiai lábnyom elemzésén kívül, sok más célra is alkalmazható. Az is belátható továbbá, hogy a bemutatott bizonytalanságok további vizsgálatok elvégzését indokolják.

\section{Irodalomjegyzék}

Blengini, G., Latunussa, C., Eynard, U., de Matos, C., Wittmer, D., Georgitzikis ... Pennington. D. (2020): Study on the EU's list of Critical Raw Materials. Final Report. Luxembourg: Publications Office of the European Union. p. 153.

Briem, S., at al., dreizehn Autoren (2005): Lebenszyklusanalysen ausgewählter zukünftiger Stromerzeugungstechniken. München: Universität Stuttgart, Institut für Energiewirtschaft und Rationelle Energieanwendung (IER); Deutsches Zentrum für Luft- und Raumfahrt (DLR), Institut für Technische Thermodynamik; Ruhr-Universität Bochum, Lehrstuhl für Energiesysteme und Energiewirtschaft (LEE); Forschungsstelle für Energiewirtschaft (FfE), p. 341.

Carrara, S., Alves Dias, P., Plazzotta, B., \& Pavel, C. (2020): Raw materials demand for wind and solar PV technologies in the transi- tion towards a decarbonised energy system. Luxembourg: Publications Office of the European Union, p. 68.

Marheineke, T. (2002): Lebenszyklusanalyse fossiler, nuklearer und regenerativer Stromerzeugung. Forschungsbericht. Universität Stuttgart, Institut für Energiewirtschaft und Rationelle Energieanwendung (IER), pp. 194-224.

Mayer-Spohn, O., Wissel, S., Voß, A., Fahl, U., \& Blesl, M. (2005, 2007): Lebenszyklusanalyse ausgewählter Stromerzeugungstechniken. Universität Stuttgart, Institut für Energiewirtschaft und Rationelle Energieanwendung (IER), p. 9.

Muteri, V., \& Curto, D. (2020): Review on Life Cycle Assesment of Solar Photovoltaic Panels. https://www.researchgate.net/publication/338384189_Review_on_Life_Cycle_Assessment_of_Solar_ Photovoltaic_Panels, p. 39

Smoucha, E., Fitzpatrick, K., Buckingham, S., \& Konox, O. (2016): Life Cycle Analysis of the Embodied Carbon Emissions from 14 Wind Turbines with Rated Powers between $50 \mathrm{~kW}$ and 3,4 MW. Edinburg University, UK, Scotland's Rural College, UK, University of New England, Australia. Journal of Fundamentals of Renewable Energy and Application, Vol. 6. No. 4. p. 10. DOI: 10.4172/2090-4541.1000211.

Wetzel, M. (2015): Materialbedarf von Stromerzeugungssystemen Szenarienpfadanalyse für Deutschland. Forschungsarbeit. Universität Stuttgart, Institut für Energiewirtschaft und Rationelle Energieanwendung (IER); Deutsches Zentrum für Luft- und Raumfahrt Institut für Technische Thermodynamik, pp. 1-99.

Wetzel, M. (2016): Materialbilanzen und Auswirkungen von Materialverfügbarkeit auf europäische Energieszenarien unter Berücksichtigung von Importen regelbaren Solarstroms. Universität Stuttgart, Institut für Energiewirtschaft und Rationelle Energieanwendung (IER); Deutsches Zentrum für Luft- und Raumfahrt (DLR), Institut für Technische Thermodynamik, p. 99.

A cikk a Creative Commons Attribution 4.0 International License (https://creativecommons.org/licenses/by-nc/4.0/) feltételei szerint publikált Open Access közlemény, melynek szellemében a cikk bármilyen médiumban szabadon felhasználható, megosztható és újraközölhető, feltéve, hogy az eredeti szerző és a közlés helye, illetve a CC License linkje és az esetlegesen végrehajtott módositások feltüntetésre kerülnek. 